\title{
The Living Fiqh, or Practical Theology, of Muslim Humanitarianism
}

\author{
Abbas Barzegar
}

Global refugee and migration flows stemming from recent economic, social, and political conflicts in the greater MENA region have become a pressing global priority for governments, NGOs, and civil society networks alike. Practitioners in these sectors are faced with competing pressures ranging from the delivery of urgent humanitarian relief and providing sustainable development solutions to counter increasingly erratic Islamophobic practices by European and American governments and media outlets. Over the course of the last three years, I have conducted ethnographic and policy research aimed at better understanding the ways faith-based humanitarian organizations operate, specifically Muslim ones, in this complex multi-sector landscape. I have explored both their logistical capacity to tackle these problems as well as the ethical and moral discourses that undergird their operational culture. In this paper, I analyze the ethical practices that emerge organically in these spaces to better understand the emergence of a distinct discourse. Provisionally, I refer to this discourse as a type of "non-secular universal humanism," that seemingly binds an otherwise incompatible set of actors together in a quest to overcome the truly impossible challenge of providing humanitarian care to forcibly displaced migrants across the MENA region and the Mediterranean corridor to Europe.

In doing so, I argue that this emerging discursive tradition, and the practices it enables, provides Muslim ethicists with a rich repository of existing customs ( Urf ) from which they can derive normative solutions and ethical positions that can address the range of complex issues engendered by the forced migration crisis. These challenges include increased sectarian division, rights to national citizenship, and presumed conflicts between humanitarian law and Islamic law. Thus, this paper proceeds in two broad sections. First, following Talal Asad's logic of understanding the living practice of Islam as a "discursive tradition" (Asad 1996), I analyze the ways in which secular, nationalist, and religious discourses converge in the practices of Muslim 
humanitarian organizations dealing with the challenge of forced migration. For this analysis, I draw upon fieldwork in Turkey among organizations such as Deniz Feneri (Lighthouse) and IHH (Humanitarian Relief Foundation) as well as upon institutional literature from Islamic Relief Worldwide that addresses migration and conflict. In doing so, I demonstrate the pervasiveness of non-secular humanistic discourse in the Muslim humanitarian sector as an emerging customary practice in global Muslim civil society. Then, in the second section I discuss how a normative Islamic ethics of universal humanism can be derived from this discursive tradition and its attendant practices by developing an integrated approach to modern methods of humanistic inquiry and Islamic ethical development. In the former, I draw upon the work of Tariq Ramadan, and in the latter, I posit the use of 'Urf. When taken together, this synthesis creates the concept of a "living figh," a term I employ to refer to the day-to-day Islamic discursive and material practices that underwrite the pervasive ethic of non-secular humanism found in the Muslim humanitarian sector.

The key feature of this approach prioritizes an empirically grounded understanding of the operative, embedded discourses, concepts, and categories that enable actors "on the ground" from secular, Christian, and Islamic backgrounds to work together in the quest to serve the needy, over and above the often abstract theological and textual justifications set forth by academics, public intellectuals, and traditional clergy ('ulama'). I argue that in these spaces and sites of social interaction, encounter, and cooperation, interesting examples of practical theology can be mapped and further explored for their potential ethical development.

The outcome of this analysis supports the positions of critical thinkers such as Talal Asad who argue for a nuanced understanding of the forces of secular logic in the post-modern period as well as moral philosophers such as Tariq Ramadan who demand that the only viable theological and ethical framework for Muslims and their secular counterparts around the world must be grounded in real-world contexts. If mapped, debated and engaged with responsibly, the discourses that emerge in the spaces of "living figh" that I have outlined above promise to provide much needed concrete examples of cooperative ethics and practical solutions to pressing problems faced by the victims of forced displacement and the resultant impact on questions concerning the place of Islam and Muslims in the contemporary world. 
The non-descript border town of Kilis, located in southern Turkey sits just forty miles north of the war-ravaged metropolis of Aleppo. An otherwise forgotten stop on an ancient trading route, Kilis found itself at the center of sectarianism, imperialism, and geopolitical rivalry. Between 2012 and 2016, the city of 90,ooo swelled to just over a quarter of a million as countless displaced Syrians fled their homes to find shelter, medical treatment, and sustainable life anywhere they could. Kilis, with its streams of humans in transit, miles of aid convoys, and overpopulated tent cities provides a useful, if callous, space to witness the emergence of non-secular humanism.

After spending an afternoon with Mahmood, a local philanthropist in his late fifties who upon first glance one would assume is a day labourer, I asked him about what kind of Islamic literature he read when he was younger. Mahmood's story was an illuminating one. I was attempting to get a sense of the intellectual motivations that drove this successful and wealthy businessman to dedicate the majority of his time and energy tending to the care of some 106 women and children whom he had housed in various locations in the city. He told me, counting off the names on his fingers, "Hassan al-Bannā, Sayyid Quṭb, Ayatollah Khomeini, Ali Shariati, Mawdūdī, Muhammad Iqbal... they all had it right, they said the same thing, and we got it wrong. But, Mawlana [Rumi] had it a 1000 years before them: Insān, Insān!" Insān, or simply mankind, was a refrain that I heard continuously among aid and development workers in the Turkish-Syrian context, but to hear it in this formula has made me think more carefully about what my interlocutors meant when they talked about humanity, or humans. In one sentence, Mahmood had managed to combine a vast and complex range of contemporary Islamic political thought and conclude that the aim of these projects was an essentially humanistic one. But the human here was clearly not the human of western liberal secularism, nor could I say that it was the human of some rarified Islamic theological vision. The humanitarian imperative for Mahmood was as self-evident as it was universal. For Mahmood, the rights of his guests (misafirim) - the term used for displaced Syrians in Turkey both legally and colloquially-were not grounded in a formal legal institution or charter, such as the international human rights regime. Rather, the rights and entitlement of those he cared for were simply ontological, yet simultaneously divinely ordained.

Mahmood's use of the term guest has larger implications, however. Turkey's President Erdogan, for example, during a Ramadan dinner in the summer of 2015 repeated a motif he had long expressed to justify his policy on hosting Syrian refugees: 
I pray this may be the last Ramadan you observe away from home. You are Muhäjirūn for us. We, as Anșārr, try to take care of our Muhäjir brothers with the love, enthusiasm, excitement of Medina. In our culture, a guest means prosperity, honour and joy. You have brought prosperity to us. You have honoured us with your presence. ("President Erdogan Shares" 2015)

Many Turkish Muslim activists and some of their Syrian counterparts imagine their relationship as a parallel to the Prophet Muhammad's flight (hijra) from persecution in Mecca to refuge and solace in Medina. The story is a foundational element in Islam's grand narrative. The themes of the Muhäjirün and Anșār pervaded virtually every conversation I had with faith based Turkish aid agencies.

Mahmood and I had this conversation in the courtyard of an old residential building that now doubled as a makeshift charity headquarters. This is where Mahmood hired a cook to prepare daily meals for his guests, received donations and supplies, as well as hosted volunteers and guests such as us. The doorway boasted a large banner belonging to Humanitarian Relief Foundation ( $\mathrm{IHH}$ ), the leading Muslim aid agency in Turkey, familiar to most of the world for its role in the Gaza Freedom Flotilla in 2010. Although Mahmood worked in tandem with $\mathrm{IHH}$, his efforts to help those in need in his hometown were of his own volition and that of his close network of colleagues and friends. $\mathrm{IH} \mathrm{H}$, however, with its central offices in Istanbul was, like most aid agencies, keen on demonstrating its presence as far and wide as possible. So, when it found an implementing partner in the person of Mahmood, it was quick to offer basic food provisions in exchange for a formal partnership.

At IH Headquarters in Kilis I was met by volunteers who, with good cause, were deeply suspicious of my presence. I asked for an interview and the group reluctantly accepted after my Turkish hosts insisted on my trustworthiness. I was given a twenty-two-year-old volunteer who participated in daily deliveries to the Aleppo countryside. He had himself only recently arrived in Kilis from a small town north of Istanbul. I asked how he and his fellow aid workers managed to conduct their work inside Syria. My question, in fact, had been a purely logistical one. He responded however with something far more existential. He told me, " $\mathrm{HH}$ has a paid staff of 500 and volunteer force of 5000 that works harder than the staff. Every day we wake up and have 70,00o orphans to feed." He continued and reminded me of the Qur'anic imperative to care for orphans, doing so with a tone of voice and body language suggesting that he lamented why something so obvious must even be explained. Like Mahmood, the young IH H volunteer understood his work as a natural outgrowth of a self-evident Islamic humanitarian ethic. 
The rhetoric of the volunteers and workers in Kilis differed drastically with that of Huseyin Oruc, the deputy director of IH H. When I inquired about the role of Muslim NGOs in the conflict he quickly corrected me and insisted that I refer to his organization as a strictly humanitarian one engaged in mainstream aid and development work. He considered the classification of IHH as a faith-based group a deliberate attempt to undermine their work; that is, he interpreted such a description as relegating $\mathrm{IHH}$ to a second-tier organization. He did make it clear, however, that what distinguishes IHH from others is their expressly political posture. In addition to advocating for taking the unique position of being both an aid agency and a human rights advocacy organization, he described IHH's position on international humanitarian law as particularly strident. He argued that IHH considered human rights, especially those of the basic entitlements of food, shelter, and safety as absolutely inviolable. IH H takes the position then that no politics or economics can or should stand in the way of the delivery of these basic services. This is the logic, he explains, that allows IH H activists and volunteers to weather the danger of war zones such as Syria to deliver aid, or to challenge the military blockade of Gaza, or to help broker local cease-fires in conflict zones around the world.

Yet, in the offices of IHн in Istanbul, one is hard pressed to find any reference to Islamic culture or thought. Rather, the décor resembles something one would expect from any mainstream international aid agency: large maps of the world, pictures of women and children in need, images of their services, and so forth. Is it the case the IH $\mathrm{H}$ deliberately conceals its Islamic orientation for the purposes of strategic maneuvering in the Turkish and international political space? It is, of course, no secret that IH H is connected to global Islamist networks and its rank and file is deeply connected to the Islamist governing party, the AKP. So why wouldn't the group simply announce its Islamist leanings overtly? I am inclined to suggest that the answer to such a question lies somewhere in the observation that humanitarianism and the notion of humanity itself has become such a vacuous rhetorical currency in global politics that a group like IH can appropriate it and give it any meaning it deems worthwhile. In this way, the Islamist vision of humanity that we see articulated casually among aid workers seamlessly weaves into global secular discourses of humanitarianism yet retains its vernacular and colloquial religious character in local vernacular. contexts.

Other large aid agencies such as Deniz Feneri and Mahmood Hudayi Vakfi, also based in Istanbul with operations around Turkey, share IHH's sense of humanitarian urgency but are much more open at higher levels of the organizations to express their overtly Islamic orientations. These groups' visions for humanitarian aid is also much more grounded in a sense of Turkish identity. 
Members from both of these groups told me on separate occasions, for example, that when doing their work they often recall the words of the medieval Turkish Sufi poet and saint, Yunus Emre (d. 1320): "We love all created beings, for the sake of the ultimate creator." Likewise, the directing manager of Deniz Feneri was eager to express to our group of visitors over lunch that charity and stewardship were integral parts of Turkish Islamic identity. He also recounted a story of an Ottoman sultan-which one and when it doesn't matter of course - who spread bread crumbs and grain on the snowy hilltops of the eastern Anatolian mountains in the dead of winter so that it could be said that even the birds were cared for under his dominion. The story is a reinvention of an early Islamic tale where the Umayyad Caliph 'Umar ibn 'Abd al-'Aziz is said to have done the exact same thing. Today there is even a charitable organization that actually feeds birds in winter in the Kurdish regions of eastern Turkey. The repetition and reinvention of this tradition, and others, speaks volumes to the imagined community that contemporary aid workers inhabit.

The narrative motifs of Islamic charity, civilization, and history surfaced in all of my conversations with aid workers and volunteers. It was clear that these were sincere discursive commitments on the part of the practitioners- that this was the world they created and occupied. It allowed them to be fully Turkish, Muslim, and human simultaneously. I argue that this discursive matrix enables a culture of non-secular humanism that underwrites a range of humanitarian and civic practices that challenge conventional paradigms of national identity as well as those of reified theological or sectarian identity. Muslim ethicists can draw upon and expand these discourses to augment a powerful resource for an emerging and transnational Islamic ethics of civic and humanitarian engagement.

\section{Islamic Relief Worldwide and Non-Secular Humanism}

Islamic Relief Worldwide (IR) is the leading independent Muslim humanitarian NGo headquartered in North American and Europe. Established in 1984 by Dr. Hany Al-Banna it now boasts a global reach, operating in dozens of countries around the world with an annual operating budget reaching nearly half a billion dollars. Although Islamic Relief and its various branches have been accused of having connections to organizations such as the Muslim Brotherhood or other Islamic revivalist and politically oriented organizations, it has consistently gained the trust of the conventional aid and development sector. Islamic Relief representatives are often the sole voice representing the Muslim humanitarian sector in leading think tanks, international organizations, and 
policy forums such as the German-led Partnership for Religion and Development, The Overseas Development Institute, and the UN Inter-Agency Task Force on Religion and Development. Given their wide reach and credibility across multiple sectors, Islamic Relief aid teams are often found on the front lines of the world's most pressing humanitarian crises. I argue that Islamic Relief can operate in these fragile and otherwise polarized contexts largely due to its religious-ideological orientation, which is deeply rooted in a vision of Islamic values and ethics but also seamlessly intertwines with a global ethic of universal human rights and citizenship recognized by the international community.

Here, I briefly review the way in which this espousal of a non-secular humanism is expressed in Islamic terms through two Islamic Relief publications that bear directly on the question of regional instability, migration and conflict in the MENA region. The first text is a small pamphlet entitled, "The Rights of Forced Migrants in Islam" which outlines the way in which the organization approaches the subject of forced migration from an Islamic humanitarian perspective (Kidwai 2014). The second, "Working in Conflict: A Faith Based Toolkit for Islamic Relief" is a conflict transformation manual taught at various levels of the organization's operational and administrative teams (Salek 2015). IR's development of this manual is in line with the increasing tendency among humanitarian actors, including faith-based organizations such as World Vision and Mercy Corps, to take a more active role in the transforming conflict scenarios that precipitate many of the crises they are asked to manage. What we find in both texts is an expression of IR's worldview that simultaneously affirms its commitment to universal, liberal, and ultimately secular conceptions of human rights as well as a faithfulness to Islamic concepts of community and human fraternity.

IR's brief pamphlet on forced migration attempts to "nurture the theological discourse on the issue of forced migration protection in Islam" in light of the fact that Muslim countries play a key role in hosting displaced peoples (Kidwai $2014,3)$. From the outset of the text we find that the subject of forced migration is positioned as both a particular problem in the contemporary moment and universal feature of human history. The pamphlet begins:

Forced migration has been a core element of the human experience throughout history. The Islamic tradition is rich with stories of forced migration and teaching on the importance of providing protection from those seeking refuge. (Kidwai 2014, 4) 
The text proceeds to discuss migration in the context of pre-Islamic prophetic history, reminding readers that figures such as Ibrāhīm (Abraham), Mūsā (Moses) and of course Muhammad were all forced migrants.

The pamphlet proceeds to equate concepts such as asylum with the idea of "security" (amān) whereby the author states that it is universally agreed upon that Muslims are obligated to provide refuge to those in need, whether "Muslim or non-Muslim, and is not dependent on political, civil, social cultural religious or economic characteristics of the fleeing person (Kidwai 2014,11). Foundational principles of the international humanitarian regime such as the right to nondiscrimination and the right to freedom of religion are also discussed through recourse to Qur'an, Tafsir, and Hadith traditions. Through these discursive practices, Islamic Relief participates in and contributes to the emergence of the culture of non-secular humanism visible in other contexts of faith-based humanitarianism.

The IR conflict toolkit provides a useful explanation of its continuing effort to balance Islamic ethics and values that are typically applied to the Muslim community in particular with a wider sense of how these ideas merge with a secular, humanistic framework. IR is explicit about its approach:

It is important to emphasize that we do not intend to work only with Muslims, or to engage in da'wah (proselytising for the Islamic faith) through our work. These tools are equally valid for use with non-Muslim communities and we actively encourage readers to redesign these appropriately. We do not advocate for a particular school of thought or make judgements about sectarian differences. Our goal is to better understand the Islamic values that motivate us to alleviate suffering, and how these values unite us across our cultural and theological differences. This toolkit aims to refer to sources across the spectrum of Islamic thought, to inspire readers to develop understanding of the connections across the Muslim world about how we are encouraged to transform conflict towards peace. (Salek 2015, 1.7)

Throughout this text, IR begins with the particularities of Islamic principles and slowly merges them with universal concepts. For example, the following description of Tawhìd [tawhid], or the Islamic concept of monotheism, is seamlessly blended with the idea of the unity of humanity:

Tawhid (unity and oneness) lies at the heart of the Islamic tradition and refers to the state of unity, oneness and uniqueness of God (Allah). Tawhid further encompasses the integration and connected nature of a 
diverse humanity as emerging from one Divine source of creation. (Salek $2015,1.14)$

The authors draw upon the well-known Qur'anic verse, "People, we created you all from a single man and a woman, and made you into races and tribes so that you should recognize one another (49:13)" to justify this appeal to the sanctity of human diversity as a feature of Islamic faith and practice.

The theme of universal human sanctity is also expressed through an elaboration on the concept of Fitra [Fitrah]:

Fitrah (sacredness and dignity of human life) recognizes the fundamental goodness of all people at birth: "We create man in the finest state ( $Q$ 95:4; see also 2:30-34, 17:70)." Because of fitrah all human life is sacred and its dignity (karama) is to be preserved: "...We decreed to the Children of Israel that if anyone kills a person-unless in retribution for murder or spreading corruption in the land - it is as if he kills all mankind, while if any saves a life it is as if he saves the lives of all mankind Q 5:32." (Salek $2015,1.16)$

The blending of the theological concepts of Tawhìd and Fitra with humanistic, secular sensibilities is indicative of an emergent, but stable tradition and custom of what I propose to refer to as the "living figh" of the Muslim humanitarian sector. Indeed, the theological concepts found in the discourses of Muslim humanitarian organizations is not merely rhetorical; in concrete situations of humanitarian relief, organizations such as IR provide aid in a neutral, unbiased way, without recourse or pretense to proselytization, sectarian bias, or ideological association.

The emergence of a non-secular humanistic discourse in the tradition of Islamic Relief's humanitarian work is perhaps most poignantly illustrated in its sublimation of the Maqāsid al-Shari'a (aims and objectives of the Shari'a) into the concept of human dignity. As we have seen above, IR has steadily found symmetry between foundational Islamic principles such as Fitra and Tawhìd and those of human rights and dignity that are pervasive in the conventional aid community. Figure 3.1, taken from the Islamic Relief "Toolkit," however, provides a powerful image of how this discursive operation unfolds in context. Taken from the section on policy, the five traditional categories of the Maqāșid (faith, life, intellect, posterity, wealth) are presented here in a floral, circular pattern reminiscent of Islamic geometrical motifs and couched within a discursive framework of "human development" and "human dignity." The image is accompanied by a set of columns with bullet points, which outline 


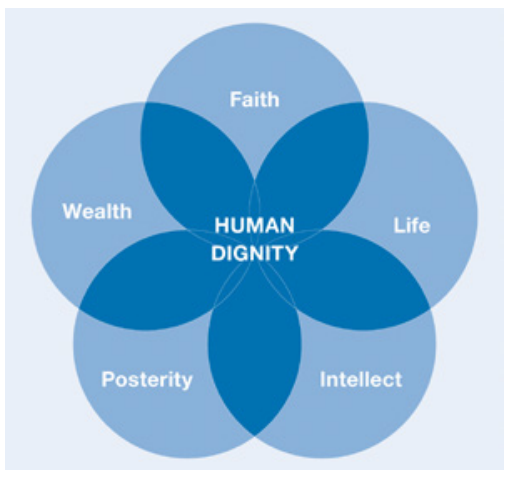

FIGURE 3.1

Five crucial dimensions of human development

various dimensions of each of the Maquassid. These characteristics include language and parlance traditionally found in the aid and development sector but adapted here under the rubric of Islamic ethics and values. For example, "humanitarianism" is categorized under "life," while "environment" is found under "posterity." This integration of Islamic humanistic values and those traditionally associated with a secular, human rights framework is among the chief characteristics of the emergent non-secular humanistic discourse found throughout the Muslim aid and development sector. As I argue in more depth in the next section, these discourses provide a stable ground through which a new tradition of normative ethics and law may be realized by Muslim ethicists and legal practitioners.

\section{Context (Wāqi $)$ : Tariq Ramadan's Call for a Socially Derived} Normative Ethics

My argument that an emergent non-secular universal humanist, but simultaneously Islamic, ethic occupies a distinct space in the political and moral imagination of Muslims in the current political moment is confirmed by observers of political Islamic formations elsewhere. Indeed, as Halim Rane argues, the "maqāsid-contextual approach" of Islamic oriented parties both in and out of the Arab world have enjoyed more electoral success than their predecessors, precisely because they have focused less on an utopian ideology that stresses "shari'a" and more on universal human values and practical programs of social reform (Halim Rane 2012-13). These examples include the election of the Nahda Party in Tunisia, the overwhelming success of the AKP in Turkey and the Prosperous Justice Party in Indonesia. Such an observation seems to corroborate my ethnographic claims that the living traditions of Islamic 
humanitarian practices undergird a new space of Muslim civic engagement whereby an ethics of global citizenship are cultivated inextricably with a sense of global Islamic revival. Islamic ethical and legal thinkers would benefit by engaging these existing practices as sources of practical ethics and law.

In advocating to derive a living figh from pre-existing spaces of Muslim civic engagement, here specifically those found in the Muslim humanitarian sector, I call for a coherent integration of social sciences and Islamic normative ethics. As we have demonstrated thus far, Talal Asad's methodological and theoretical concept of understanding Islam as a "discursive tradition" has enabled us to analyze social and cultural contexts through an anthropological framework. In doing so, we have identified examples of a living figh whereby Muslims engage humanitarian work with universally informed moral and ethical principles that are coterminous with their interpretations of Islamic theology and law.

In our current case, I posit that Muslim humanitarian practices can inform emerging Islamic legal and ethical approaches to civic engagement, democratic culture and global citizenship by virtue of the fact that existing custom (' $U r f$ ) of Muslims in these spaces has now come to prioritize humanistic principles that transcend national, ethnic, sectarian, and ideological affiliations. At the same time, these practices are thoroughly fused with the larger aims and objectives (maqāsid) of Islam and Shari'a and thereby have become part of the customary understanding of Islamic truth by millions of Muslims around the world. These practices, which are informed by subtle interpretations of Islamic ethics, provide the "data" or living texts that can help ethicists and legal thinkers better determine norms and guidelines to develop timeless Islamic solutions to contemporary and particular problems.

To further make the case that the social scientific observation of Muslim practices should be used as a source of Islamic normative thinking, I now turn to Dr. Tariq Ramadan's notion of context or wāqi' to serve as the hermeneutical bridge needed to integrate the largely disconnected realms of ușül al-figh and modern social sciences. Here, I draw upon Ramadan's call to not only integrate, but to center wāqi or context based knowledge as a primary source in determining contemporary Islamic ethical practices. I do so to then (re)introduce the principle of ' $U r f$ as a source of Islamic law that grounds the notion of living figh within a broader tradition of both contemporary and historical Islamic hermeneutics.

Ramadan begins his discussion about wāqi $i^{i}$ with a reminder that among the many divine mandates of the Qur'an is the continual invitation to ponder and analyze the existing universe as an unfolding revelation of God's truth in and of itself. He argues that this element "affects all the areas of human knowledge about the created Universe: a Universe that is both a gift and a "sign" fraught 
with meaning and its Creator, as we have seen, keeps inviting "those who are endowed with insight" to observe, study, and analyze it in all its dimensions (Ramadan 2008, 104). From this vantage point, Ramadan encourages the ethicist to move beyond the conventional modern tradition of using scientific reason to "prove" the truth of revelation and rather engage in a deep understanding of the human culture, tradition and art as an equally valid source of augmenting Islamic ethical and legal norms. By elevating the truth found in the social sciences to that of the natural or empirical sciences, he enables thinkers to contextualize the interpretation of Islam in the contemporary moment as part of a continuation of tradition, rather than a break from it.

To accomplish this, however, Ramadan must differentiate between the two broad types of interpretive conclusions used in Islamic legal judgements: $q a t^{t} i$ (certain, definitive) and zanni (speculative). He argues that one realm of the social sciences attempts to identify the underlying universal principles and laws that undergird human behavior historically:

The constants in the various legislative models, relations to power, domination structures, the relationship to politics, the historical behaviors of the rich and the poor, and symbolic expressions, match logical patterns and causality principles that may be verified even though those are not exact and scientifically definitive. The laws underlying the diversity of phenomena remain operative and universal and in this respect they are similar to the qați category as to their qualification. One cannot, in the social sciences, deny or overlook the presence of constants explaining human behavior patterns. (Ramadan 2008, 107)

Ramadan is less concerned, however, with this area of the social sciences because despite significant levels of debate, in his opinion the quest for generalizable principles in the social sciences is similar to that in the natural sciences. What is more challenging is understanding society, social norms, and human behavior in particular and concrete historical moments that are fluid, subject to change, and politically contested.

The challenge of deriving principles for Islamic ethics that are contextually grounded is due to the highly speculative (zanni) nature of these interpretative conclusions. Acknowledging the inconclusive nature of contextual readings of cultural norms and social change, Ramadan argues that human reason and "constant ijtihād" defined as an "autonomous critical approach" can serve as guides to support navigating this complex interpretative space. Precisely because they are speculative and require the rigorous reflection of human reason, they demand particular attention. I quote Ramadan at length: 
The Book of the Universe and the social sciences that unfold there open the doors of the zanni that requires human reason to perform a constant ijtihād (autonomous critical approach) to identify enduring or/and changing causality principles, the various relationships to cultures and/ or customs, symbolical and/or imaginary projections, and the like. A vast field thus opens for the exercise of human rationality, and it is by no means less important because it contains less certain knowledge than the exact or experimental sciences: on the contrary, it is because of the need to be in direct contact with the lived reality and with human behavior (in its diversity in worldly time) that specific attention must be paid to the social sciences as a whole. What they teach us about humankind, about indeterminate elements in groups and in human behavior, in value systems and in cultures-although this is zannī (open to interpretation) or rather all the more so because it is zanni-is essential to any intellectual exercise striving to remain faithful to the ethical meaning of the revealed Book. It is indeed in this field of the zanni that jurists elaborated the main part of their reflections: at the heart of diversity, of the nonorganic, the seemingly unorganized, they tried-by deduction as well as by inference-to suggest ways of respecting faithfulness to the global, and invariably positive, message of scriptural sources. The social sciences, the many specializations in the observation and understanding of reality, play the same part and it would be unthinkable - and quite illogical and absurd - to cut oneself off from those fields of knowledge because they offer nothing "certain" or because behaviors, or even "moral categories," appear there as indeterminate or contradictory. (Ramadan 2008, 107-8)

Ramadan's insistence that context-specific zanni interpretations of human behavior and culture provide a basis for ethical and legal determination may seem broad and inconclusive to some critics who then argue that no concrete solution to pressing social problems is made by such an intervention. Such a criticism is, in part, correct but ultimately misguided.

It is the case that the call to rely upon ijtihād or human reason is open ended and categorically inconclusive. However, Ramadan's call to rely upon these tools aims precisely to urge that Muslim ethicists-to phrase it in my own words - embrace and determine the course of their own tradition, to develop it, to curate it. In advocating an open-ended, zanni approach to using the social sciences as a source of law, Ramadan is encouraging contemporary scholars to follow in the footsteps of Islamic civilization's great thinkers, rather than simply mimic them. He concludes: "the first Companions, as well as early scholars, 
confident, as we said, in the Revelation's global message and intimately familiar with their natural environment, never refrained from including the latter in their legal elaborations" (Ramadan 2008, 108). Ramadan's call therefore is one of actionable intelligence-a call to intervene in and reform the ethical stagnation that plagues many quarters of the Muslim intellectual milieu. In order to address the overwhelming ethical, social, and political challenges posed by the forced migration crisis, it is imperative that Muslim thinkers in the contemporary moment develop conceptual frameworks that are both theologically and practically viable. In the remainder of this essay, I argue that 'Urf (customary practice) is a conceptual tool that can satisfy the multiple demands faced by Muslim ethicists today.

I close this essay with a (re)introduction of the concept of custom ( $U r f$ ) as a means through which contemporary Muslim ethicists may consider concretizing the existing practices of non-secular Islamic humanism found in the Muslim aid and development sector into a normative Islamic ethical tradition. I also argue that 'Urf provides an intellectual basis to allow for the project of deriving norms from the lived context (wāqi). Taken together, I posit that the complex challenges of sectarianism, ethno-nationalist citizenship, and political ideology can be mitigated by developing the emerging custom ( $U r f)$ of non-secular Islamic humanism found in the Muslim humanitarian sector into a viable normative Islamic ethical tradition.

As part of a multi-generational effort of reformist theology, Muslims have developed contemporary interpretations of fiqh, akklāq, and Shari'a that are intended to better enable Muslims ways to navigate the complex social space of religious and political identity in the era of the modern nation state. As part of this conversation, it has long been argued that classic Islamic ethnical formulations of political community remain at odds with modern concepts of citizenship and equality. Critics and reformists alike point to structures such as the jizya $\bar{a}$ system of non-Muslim taxation or concepts such as al-walä' wa-albara $\vec{a}$, which encourage communal solidarity and repudiation of non-Muslims as examples of the incompatibility of Islamic political ethics and modern norms of universal humanism. While most of this discussion takes place in the abstract and theoretical, I use the practice of Muslim humanitarianism as a site to explore how contemporary practices of Muslim communal solidarity intersect with the international norms of neutrality and impartiality. I argue that, contrary to the alleged tension between Muslim identity and modern 
universal humanism, the practice of Islamic humanitarianism is embedded in and embodies a rich discourse of non-liberal, universal humanism grounded in a deep discursive and performative tradition of Islamic ethics. I argue that this non-secular humanism constitutes a source of 'Urf, or custom, that can be considered a site through which contemporary Muslim practices can serve as a basis for sustained ethical cultivation.

As noted by a range of scholars such as Hashim Kamali, Anver Emon, Gideon Libson, and Ayman Shabana among others, while it is well known that although custom is not formally recognized as a source of law, Muslim jurists and theorists have consistently incorporated it into their determination of law and ethics (Emon 2006; Kamali 2005; Shabana 2010; Libson 1997). In the modern period, 'Urf has played a central role in the revival and reformation of Islamic ethics in a range of contexts. As Ayman Shabana, whose research provides a useful overview of the subject's treatment in classical and modern scholarship notes:

Urf, as well as similar legal principles such as maslahah, was an important legal tool that Muslim reformers invoked in their efforts to work out a comprehensive methodology to bridge the gap between the past and the present on the one hand and legal theory and practice on the other. (Shabana 2010, 41)

Indeed, the writers of the late Ottoman Mejelle and leading modern Muslim intellectuals such as Rashīd Rị̣ā and Muhammad Amīn Ibn 'Ābidín (d. AH 1252-1836 CE) looked to Urf as one of the main mechanisms through which the practice of ijtihād could be used to address a range of emerging social problems and questions. The prolific scholar, Mohammad Hashim Kamali, likewise has given special attention to the depth and nuance of $U r f$ as a source of Islamic jurisprudence. He points to the broad utility, even democratic nature of 'Urf in that it: 1) requires broad but not uniform consent; 2) depends on popular affirmation, not just a decision by the mujtahids; 3 ) is changeable in light of differing times and circumstances; and 4) depends on gradual acceptance over time (Kamali 2003, 375-76). The two different types of 'Urf: approved (șahīh) and disavowed ( fäsid) also provide a mechanism through which cultural practices are identified as compatible with emerging norms and positive principles or should be discarded as unacceptable (Kamali 2003, 376).

The precedent of taking custom seriously throughout Islamic civilization and history is indicative of a strong tradition of independent thinking and practice among jurists and ethicists that seemingly strengthens over time. Here I draw upon the work of the scholars mentioned above to outline some of the textual sources and genealogies of custom as an authoritative tradition in 
order to augment the authority of Ramadan's call to ground contemporary judgements in living context (wāqi).

The strongest explicit support for custom as a source of law seems to have come from the pen of Muḥammad ibn Aḥmad al-Sarakhsī (d. 49o/1097) who mentioned custom as a source of law when discussing the conditions of a jurist's capacity for independent reasoning: "if a mujtahid is familiar with the Qur'an ... and with the Sunna, and if he is an expert in qiyās and knowledgeable with regard to the custom" (Lisbon 1997, 138). In this instance al-Sarakhsī seems to suggest that custom is on par with the foundational sources of Islamic law. That al-Sarakhsī mentions custom instead of $\ddot{j} m \bar{a}^{c}$ as might be expected is representative of a larger and deeper tradition among jurists to equate the two. In most cases, custom was sublimated into other sources of law and hermeneutic tools. For example, Mālikīs would assume the custom of Madina as a standard part of the Sunna and Hanafiss would often use the principle of preference (istihsānn) to incorporate local custom into law and ethics.

By the post-classical period, custom seems to have become a very normative feature of the Islamic legal landscape. Ibn Nujaym (d. 970/1563), for example, notes:

Know that the consideration of custom and usage reappears frequently in law in many cases, so much so that they [viz., the jurists] have transformed it into a legal source, and they said in the ușūl literature, in the chapter on the abandonment of literal meaning: the literal meaning is abandoned on the basis of an indicator found in inferential methods of inquiry and in custom. (Lisbon 1997, 141)

As Gideon Libson notes, this trend to close the gap between practice and theory on the role of custom continued into the late Ottoman period, where it was codified in the Mejelle as a source as authoritative as revelation itself: Article 45 reads "Whatever is dictated by custom is as if dictated by Scripture" (Lisbon 1997, 154). Although few would accept this logic or find a viable route to apply it, the fact remains that custom is one of the richest sources of Islamic ethical and legal thinking available to contemporary jurists and ethicists.

In closing, however, I would like to highlight another feature of utilizing custom as a source of law that I find important for the contemporary conversation on legal reform: the demand of autonomous and independent juristic discernment. Most sources of law are textual. Aside from the Qur'an and Sunna, even the precedents found in qiyās, $\ddot{j} m \bar{a}^{c}$, and the qawā $c$ are deeply rooted in a textual tradition that often positions the jurist or ethicist in a secondary or tertiary role in arriving at a conclusion. While this is not actually 
the case in practice given that scholars always apply their own thinking to a problem, textual fidelity often obfuscates and hides the amount of independent thinking taking place in the way a scholar approaches a problem. Reliance on custom, however, demands that jurists engage in an autonomous act of discernment. Custom demands a sound, but ultimately subjective, analysis of a fluid and dynamic social context, echoing Ramadan's discussion above about the incorporation of the social sciences and humanities in contemporary Islamic thinking.

In the past, this process seems to have been less controversial than it may be today. A concise statement that sums up how simple, yet powerful, 'Urfactually is has been attributed to Imām al-Ghazālī: "Custom is that which is established in a man's mind by virtue of logic and the sound mind accepts it (Libson 1997, 141)." It is interesting to note that the criterion for "logic" and "sound mind" here are not elaborated upon or discussed in detail. In fact, much of the legal literature on custom assumes it to be self-evident which essentially empowers and entrusts the jurist to come to their own conclusion on the subjects. This conclusion, however, was determined by the wider sense of what the community considered acceptable, appropriate, and viable. The pervasive legal maxim (qawāid fiqhiya), "al-āda muhakkama" (custom is binding), which underwrote a range of legal discussions, was often justified in the saying of Ibn Mas'ūd, which was also cited as a Prophetic hadith: "That which the Muslims see as good is considered good by God." Here, again, we see a position for Muslims to understand custom as self-evident, binding, and legally sound.

\section{Conclusion}

The "living figh" of Muslim humanitarianism that is non-secular and also nonsectarian should be understood as a rich repository of practical custom ('Urf) through which Muslim ethicists can develop concrete normative positions, which can help bridge the presumed gulf between secular humanism and the classical Islamic tradition. That is, rather than creating a theological justification from classical sources to justify or persuade practitioners of the potential for an integrated Islamic and secular ethics, the normative traditions emerging in the Muslim humanitarian sector offer a repository of discursive resources that are already operative in social life and thoroughly entangled in both Islamic and secular traditions. The ethicist's position becomes then, not one to convince or argue for a potential normative stance, but merely to augment it. In a sense it is to provide a "reverse reification" of existing practices in order to ensure that they are not treated as merely anecdotal or happenstance, but rather supported 
by legitimate hermeneutical traditions. For such a reverse reification to take place and remain viable, Muslim ethicists need to draw upon intellectual practices grounded in classical Islamic traditions as they formulate their positions. Here, I have suggested that they draw upon practice of ' $U r f$ to do so.

The contemporary challenges of the forced migration crisis for Muslim ethicists and scholars are staggering. The MENA region and its immediate environs are plagued by internecine and sectarian feuds in fragile political contexts where foundational problems of citizenship, identity, and citizen rights continue to evade resolution. In the midst of this turbulence, the transnational Muslim aid and development sector, through its continued engagement with universally recognized principles of humanitarian engagement, has developed a living tradition of customary practice that prioritizes the unconditional rights of beneficiaries over and above considerations of nationality, religion, or sect. As we have seen, the discursive environment that enables these practices is firmly grounded in Islamic discourses, texts, and traditions, leaving no question as to their compatibility with the historic tradition of a multitude of Islamic civilizations and cultures. It has been my argument that Muslim ethicists, jurists, and intellectuals will recognize that the belaboured discussions and questions surrounding the relationship between the Shari'a and issues such as citizenship and human rights can be rejuvenated in this dynamic and largely understudied social space. Such an agenda of intellectual practice promises to not only answer theoretical questions of law and ethics entertained by Muslims in the modern period for generations, but also provide ethical and moral guidance to help arrive at a shared vision for resolving a humanitarian crisis that promises to remain with the global community for generations to come.

\section{Bibliography}

Asad, Talal. 1996. The Idea of an Anthropology of Islam. Center for Contemporary Arab Studies, Washington D.C.

2015. "President Erdoğan Shares Fast Breaking Dinner with Refugees at Midyat Accommodation Center," Presidency of the Republic of Turkey. Retrieved from: <https:// www.tccb.gov.tr/en/news/542/3277o/president-erdogan-shares-fast-breaking-din ner-with-refugees-at-midyat-accommodation-center.html>. Accessed May 17, 2018.

Emon, Anver. Dec. 2006. "Conceiving Islamic Law in a Pluralist Society: History, Politics and Multicultural Jurisprudence." Singapore Journal of Legal Studies, 331-355.

Kamali, Mohammad Hashim. 2005. Principles of Islamic Jurisprudence. Islamic Texts Society. 
Kidwai, Sadia Najma. 2014. "The Rights of Forced Migrants in Islam." Islamic Relief Worldwide. Birmingham.

Libson, Gideon. 1997. "On the Development of Custom as a Source of Law in Islamic Law." Islamic Law and Society 4(2), 131-155.

Ramadan, Tariq. 2008. Radical Reform: Islamic Ethics and Liberation. London: Oxford University Press.

Rane, Halim. 2013. "The Relevance of a Maqāṣid Approach for Political Islam Post-Arab Revolutions." Journal of Law and Religion 28(2), 489-520.

Salek, Lucy. 2015. "Working in Conflict: A Faith Based Toolkit for Islamic Relief." Islamic Relief Worldwide. Birmingham, uk.

Shabana, Ayman. 2010. Custom in Islamic Law and Legal Theory. New York: Palgrave Macmillan. 